\title{
Driving License Management Services In Preventing Traffic Accidents
}

\section{Puguh Agung Dwi Pambuditomo*) and Widayati**)}

*) Student of Master of Law, Faculty of Law, Universitas Islam Sultan Agung (UNISSULA) Semarang, E-mail: pakpuguh1@gmail.com

$\left.{ }^{* *}\right)$ Faculty of Law, Universitas Islam Sultan Agung (UNISSULA)

\begin{abstract}
.
In the Blora Police jurisdiction, the number of traffic accidents from year to year has increased. One of the efforts to reduce the rate of traffic accidents is by making SIM services according to the correct procedure. The purpose of this study was to determine and analyze the service for making a driving license (SIM) at the Blora Police in order to prevent traffic accidents and to find out and analyze the obstacles faced by the Blora Resort Police in making a driving license and their solutions. The approach method used is sociological juridical, descriptive analytical research specifications. Types and sources of data are primary data and secondary data. The data collection methods are field studies and literature studies. The data analysis method uses qualitative analysis. The theory of public service, law effectiveness and benefit theory is used as an analysis knife. The results showed that the service for making a driving license (SIM) at the Blora Police in order to prevent traffic accidents has been implemented in accordance with applicable statutory procedures and can be said to be effective in reducing accident rates. The problem faced by the Blora Resort Police in making a driving license is the lack of number of personnel. The solution is to divide the service into two groups, namely applicants for new SIM and applicants for SIM extensions; the timeliness of service is not in accordance with the SOP, the solution is to immediately take a theoretical test every time a participant has a If there is equipment damage in the SIM service, the solution is to wait for the technician to arrive while still performing services using the available equipment; and lack of public awareness and understanding, the solution is by socializing the community.

Keywords: Driving License; Services; Preventing; Traffic Accidents.
\end{abstract}

\section{Introduction}

The police is a government agency that provides services to the community. The Police of the Republic of Indonesia are part of the functions of the State government in the field of maintenance and security, public order, law enforcement, protection, protection, and services to the community. It can be said indirectly that the police are very attached to public services.

Public services can be interpreted as all forms of services, both in the form of public goods and public services which in principle are the responsibility and are implemented by government agencies at the central, regional, and in the environment of State-Owned Enterprises or Regional-Owned Enterprises, in an effort fulfill the needs of the community as well as in the framework of implementing the provisions of laws and regulations. ${ }^{1}$

${ }^{1}$ Hardiansyah. (2011). Kualitas Pelayanan Publik; Konsep, Dimensi, Indikator dan Implementasinya. Yogyakarta: Gava Media. p. 11. 
In the implementation of quality public services, there must be elements of public service that are fulfilled so that these activities can be said to be public service activities, including 1) systems, procedures and methods; 2) personnel; and 3 ) facilities and infrastructure. ${ }^{2}$

The government functions carried out by the Police concern law enforcement activities, protection, protection and advisory services to the community. These tasks are closely related to the daily social tasks that people face. One form of service provided by the National Police is the SIM manufacturing service which is implemented by the Traffic Unit (Satlantas).

Satlantas is part of the Police which is an element of executing the main tasks under the Chief of Police8. This is as confirmed in Article 59 of the Chief of Police Regulation No. 23 of 2010 which states that the Traffic Police is an element of executing the main tasks under the Kapolres, which in carrying out its duties one of which is administrative services for registration and identification of motorized vehicles and drivers. ${ }^{3}$

Based on the provisions of Article 87 paragraph (2) of Act No. 22 of 2009 concerning Road Traffic and Transportation, a Driving License (SIM) is issued by the Indonesian National Police. Furthermore, Article 87 paragraph (3) states that the National Police is obliged to organize an information system for the issuance of driving licenses. SIM according to Article 1 number 4 Perkap Polri Number 9 of 2012 is proof of the legitimacy of competence, control devices, and police forensic data for someone who has passed the knowledge, ability and skill test to drive a motorized vehicle on the road in accordance with the requirements determined by law. -The Law on Traffic and Road Transportation. Thus, someone who has a SIM is considered to have the competence to drive a motorized vehicle after passing the exam.

In the Blora Police jurisdiction, the number of accidents has increased from year to year. Accident data at the Blora Police show that in 2017 the total number of traffic accidents was 386, while in 2018 it was 421. One of the causes of accidents was that the driver was not yet competent in driving a vehicle.

Satlantas Polres Blora is required to be able to make a public policy in providing its services to the community. With the problem of the high number of traffic accidents that exist and the high number of fatalities from each accident, Satlantas must take a policy in carrying out its duties, functions and roles in providing services to the community as a representation or an extension of the government to overcome these problems. . ${ }^{4}$

Several attempts have been made to reduce the rate of traffic accidents, one of which is by making SIM services according to the correct procedure, namely through a number of tests for registrants. In fact,SIM service at Polres Blora shows

\footnotetext{
2 Istianto, Bambang. (2011). Manajemen Pemerintahan Dalam Perspektif Pelayanan Publik, Jakarta: Mitra Wacana Media.p. 123.

${ }^{3}$ Sugiyanto, Bhakti Satriya Perdatana \& Gunarto. (2018). "Peran Satlantas Polres Rembang Dalam Menanggulangi Tingginya Kecelakaan Akibat Parkir Liar (Studi Kasus di Kabupaten Rembang)", Jurnal Daulat Hukum, Volume 1 No. 1, March. p. 142.

4Purnomo, Dadik \& Jawade Hafidz. (2018). "Peran Sat Lantas Polres Rembang Dalam Menekan Angka Kecelakaan Lalu Lintas", Jurnal Daulat Hukum, Volume 1 No. 1, March. p. 283.
} 
that it has not been effective and efficient. This can be seen from the prevalence of brokers / intermediaries in SIM-making services, so that people have to pay more to be able to get a SIM and there may be people who are not proficient in driving a vehicle but can get a SIM. In addition, the service of police officers in acting and responding to the wishes of service users is an assessment of the community. The arrogant, unfriendly attitude of the police towards the community in handling SIM making has created a negative image from the public towards the Police. Some people even tend to use the services of brokers / brokers because it is faster and easier to get a SIM without having to undergo various examination procedures.

\section{Research Methods}

The approach method used in this research is the empirical juridical approach method, namely research based on normative legal science (laws and regulations), but not examining the norm system but observing how the reactions and interactions occur when the norm system works in society. ${ }^{5}$ The research specification is descriptive analytical, the source and type of data used are primary data and secondary data. The data collection method was carried out through field studies and literature studies. Methods of data analysis using qualitative analysis.

\section{Results and Discussion}

\subsection{Services for Making a Driver's License (SIM) at the Blora Police in order to prevent traffic accidents}

The results showed that the SIM making service, Satpas Polres Blora already has service standards that are used as guidelines or references in serving people who want to make SIM and also behavior guidelines for each member in SIM services. SIM-making services at the Blora Police Traffic Police are carried out in accordance with applicable statutory procedures, namely Act No. 22 of 2009 concerning Road Traffic and Transportation and Perkap Polri Number 9 of 2012 concerning SIM. The implementation of SIM services at the Blora Police Satpas to the public has been going well, where SIM applicants have understood the costs and flow of SIM making, because in addition to installing the PNBP PP Tariff board Number 60 of 2016, the Blora Police Traffic Unit has also conducted socialization to the public.

The SIM service mechanism at the Blora Police Satpas has provided clarity to SIM applicants to know the requirements and fees set and must go through theoretical and practical exams and must pass an exam if they are going to get a driving license (SIM) and if they do not pass theoretical or practical exams, then SIM applicants must return to the management within the next 3 months. Through this mechanism directly it is hoped that SIM applicants will gain theoretical knowledge of traffic laws, traffic signs,

\footnotetext{
${ }^{5}$ ND, Mukti Fajar \& Yulianto Achmad. (2013). Dualisme Penenlitian Hukum Normatif dan Empiris, Yogyakarta: Pustaka Pelajara. p. 47.
} 
In terms of public service theory, SIM making services at the Satpas Polres Blora are basically aimed at community satisfaction. To achieve this goal, public service providers are required to improve quality. ${ }^{6}$ At the Blora Police SIM Service Satpas, a standard service policy has been established, namely improving the quality of public services (faster, cheaper, safer, and easier to reach) in government agencies as well as increasing the index of community satisfaction with the delivery of public services by each agency. government.

Satpas SIM Polres Blora services in public service providers are required to improve the quality of services carried out in accordance with service principles, which include simplicity, clarity, certainty of time, accuracy, security, responsibility, completeness of facilities and infrastructure, easy access, discipline, politeness. and friendliness, and comfort. ${ }^{7}$

SIM-making services at Polres Blora in preventing traffic accidents in terms of legal effectiveness theory, that law enforcement can be effective if: ${ }^{8}$

- There is a relevance of the rule of law to the needs of the target people.

- There is clarity in the formulation of the substance of the rule of law

- Optimal socialization to all people who are targets of the law.

- The sanctions that will be threatened in law must be matched with the nature of the law being violated.

Based on the description above, it can be seen that in terms of the theory of legal effectiveness, the SIM service at the Blora Police Satpas can be said to be effective. This can be seen from the data on the issuance of SIMs at the Blora Police Satpas in 2019 which issued 39,994 new SIMs. If it is related to the number of accidents that occurred in 2019, which was 393 incidents, this shows a decrease in the accident rate compared to 2018 which was 421 incidents.

The SIM service at the Blora Police Satpas fulfills the benefit theory as put forward by Jeremi Bentham, which states that to assess a public policy brings benefits or brings harm can be seen from the impact it has on many people morally. ${ }^{9}$ The SIM service at the Blora Police Satpas has actually provided benefits for people who want to meet their needs in obtaining a certificate of evidence that they are competent to drive vehicles on the highway. To obtain a SIM, the community must pass a number of exams, both theoretical and practical exams. This is useful to determine whether someone is eligible for a SIM. A person who already has a SIM means that he has competence in driving a motorized vehicle on the highway. This can prevent traffic accidents, because drivers already know the technique of driving a motorized vehicle well. Thus it can be said that the SIM service at Polres Blora has provided benefits to the community.

\footnotetext{
6Sinambela, Lijan Poltak. (2010). Reformasi Pelayanan Publik. Jakarta: PT. Bumi Aksara. p. 6.

7 Chalik, Abdul \& Muttaqin Habibullah. (2015). Pelayanan Publik Tingkat Desa. Yogyakarta: Interpena. p.27.

8 Ibid.

${ }^{9}$ Keraf, Sonny. (1998). Etika Bisnis Tuntunan dan Relevansinya. Yogyakarta: Kanisius. p. 93-94
} 


\subsection{Constraints faced by the Blora Resort Police in the Service of Making a Driving License (SIM) and their Solutions}

These obstacles faced by the Blora Resort Police in SIM Making Services are: ${ }^{10}$

- Lack of personnel in SIM services

The number of personnel at the Satpas SIM service at Polres Blora is 15 people with their respective duties and functions. However, every day there are members who have to carry out official duties such as traffic pickets, following traffic activities so that the number of personnel decreases.

- There is no timeliness as stipulated in the SOP

Based on the SOP for SIM services, the time needed for new SIM services A, C and D is 120 minutes, for general SIM A, B1, B1 General, BII and B II general is 180 minutes. In practice, the time required is longer than that specified in the SOP. This is due to the large number of participants, so the queue for theory exams and practical exams is also getting longer.

- There is damage to the equipment in the SIM service

There are times when the equipment gets damaged. To repair the damage, you cannot immediately call a technician so that you can repair it immediately, but you have to wait for a technician from the Regional Police or the National Police Headquarters. This is because there is data that is confidential so it must be kept confidential.

- Lack of public awareness and understanding in making SIM

Public understanding of the mechanism for making SIM is still lacking, especially in rural communities. The large number of participants who failed the exam ultimately made people lazy to re-test and took shortcuts by using brokerage services.

According to Soerjono Soekanto, the measure of effectiveness in law enforcement is based on five things, namely legal factors, law enforcement factors, supporting facilities and facilities, community factors and cultural factors. ${ }^{11}$ In terms of statutory factors, basically the regulations regarding the mechanism for making SIMs have been regulated in the Land Transportation (LAJ) Law, Perkap Polri Number 9 of 2012 and regarding the SIM fee rates have been regulated in PP Number 60 of 2016. The provisions of these regulations are further outlined in Service SOPs Blora Police Satpas SIM, including the standard time for making SIM. In practice, the time required is longer than the time specified in the SOP.

In terms of law enforcement factors, the thing that hinders SIM services at the Blora Police Satpas is the lack of personnel in SIM services due to several officers who clash with picket schedules, so they cannot serve the public in making SIM. This resulted in the SIM service being ineffective. Judging from the factors of supporting facilities and facilities, damage to computer equipment as a means of SIM services can hinder the process of services provided to the community. Moreover, to repair the equipment, a special technician must be brought in from the Polda or Polri Headquarters, so that the SIM service becomes ineffective. In

\footnotetext{
${ }^{10}$ Interview with AIPTU Juremi, as the Blora Police Traffic Traffic Police, in Blora on July 20, 2020 ${ }^{11}$ Soekanto, Soerjono. (2007). Faktor-Faktor yang Mempengaruhi Penegakan Hukum. Jakarta: PT. Raja Grafindo Persada. p. 5.
} 
terms of community factors in terms of community facts, there are still people who do not have awareness and knowledge of SIM building, so that there are still those who use the services of brokers / brokers. The constraints mentioned above resulted in the ineffective SIM service at the Blora Police Satpas.

The solutions to overcome these obstacles are as follows:

- Sharing SIM services for new SIMs with renewed SIMs simultaneously.

The solution to overcome the lack of personnel is to divide services into two groups, namely applicants for new SIM and applicants for SIM extensions.

- Implementation of theoretical exams without waiting for full participants

The solution to overcome the inadequacy of service time with SOPs is to immediately take a theoretical test every time a participant registers without having to wait for the number of participants to reach 10 people, so as to shorten the queue time on the theory exam.

- Carry out services with makeshift equipment

The solution to dealing with equipment damage is to wait for the technician to come to repair it while still performing services using the available equipment. For this reason, a new theory is needed, where each Polres should provide technicians or recruit technicians from the private sector for training. This aims to expedite the SIM making services, to meet the needs of the community in obtaining services.

- Conducting outreach to the community

The solution to overcome the lack of knowledge and public awareness of the Blora Police Traffic Unit is to socialize to the wider community. The public is encouraged to make a SIM according to the correct procedure and not to use the services of brokers / brokers. As for the efforts made by the Blora Police Traffic Unit to eliminate brokers / brokers is to carry out internal supervision in the Blora Police Traffic Traffic Unit to curb the brokers.

\section{Conclusion}

SIM making services at the Blora Resort Police in order to prevent traffic accidents can be said to be effective, as shown by the data on the issuance of new SIMs in 2019, namely 39,994 pieces associated with the number of accidents that occurred in 2019, namely 393 incidents where there was a decrease compared to 2018, 421 incidents. The obstacle faced by the Blora Resort Police in making SIMs is the lack of number of personnel. The solution is by dividing services into new SIM applicants and SIM extension applicants; the timeliness of service is not in accordance with the SOP. The solution is to immediately carry out a theoretical test every time a participant is present, there is equipment damage in the SIM service. The solution is to do the service while waiting for the technician to come to repair the equipment.

\section{References}

Journals:

[1] Sugiyanto, Bhakti Satriya Perdatana \& Gunarto. (2018). "Peran Satlantas Polres Rembang Dalam Menanggulangi Tingginya Kecelakaan Akibat Parkir 
Liar (Studi Kasus di Kabupaten Rembang)", Jurnal Daulat Hukum, Volume 1 No. 1, March.

[2] Purnomo, Dadik \& Jawade Hafidz. (2018). "Peran Sat Lantas Polres Rembang Dalam Menekan Angka Kecelakaan Lalu Lintas", Jurnal Daulat Hukum, Volume 1 No. 1, March.

Books:

[1] Chalik, Abdul \& Muttaqin Habibullah. (2015). Pelayanan Publik Tingkat Desa. Yogyakarta: Interpena

[2] Hardiansyah. (2011). Kualitas Pelayanan Publik; Konsep, Dimensi, Indikator dan Implementasinya. Yogyakarta: Gava Media

[3] Istianto, Bambang. (2011). Manajemen Pemerintahan Dalam Perspektif Pelayanan Publik, Jakarta: Mitra Wacana Media

[4] Keraf, Sonny. (1998). Etika Bisnis Tuntunan dan Relevansinya. Yogyakarta: Kanisius

[5] ND, Mukti Fajar \& Yulianto Achmad. (2013). Dualisme Penenlitian Hukum Normatif dan Empiris, Yogyakarta: Pustaka Pelajara

[6] Sinambela, Lijan Poltak. (2010). Reformasi Pelayanan Publik. Jakarta: PT. Bumi Aksara

[7] Soekanto, Soerjono. (2007). Faktor-Faktor yang Mempengaruhi Penegakan Hukum. Jakarta: PT. Raja Grafindo Persada

\section{Regulations:}

[1] Act No. 2 of 2002 concerning the Indonesian National Police

[2] Act No. 22 of 2009 concerning Road Traffic and Transportation

[3] Act No. 25 of 2009 concerning Public Services

[4] Chief of Police Regulation Number 9 of 2012 concerning Driving License.

Interview:

Interview with AIPTU Juremi, as the Blora Police Traffic Traffic Police, in Blora on July 20, 2020 